\title{
Editorial
}

\section{A clarion call to debate notions of equality and struggles around power}

Much has happened in the world since the first issue of the Journal of Social Inclusion (JoSI) in April 2010. The uncertainty of the past few years and complexities in the ways communities handle social debates have spilled into the parliamentary arena and beyond. The polarised party politics of Left and Right are fragmenting and another space of convergence around interests is emerging. Marginalised peoples with lives that are often socially, economically or emotionally precarious, hang in the balance as time-honoured perspectives around wel(fare), diversity, tolerance and development are up for grabs. Countries in the global South are influenced by political, social and ideological developments of other nations, especially those of G7 countries. Public discourse invokes issues around recalling the impact of past events in the treatment of marginal sections of society and the enduring legacies of social policy decisions.

To avoid a hung parliament, the United Kingdom formed its first coalition government in May with the Conservative Party and Liberal Democrats. Under the three principles of freedom, fairness and responsibility, the coalition promises to "take Britain in a historic new direction, a direction of hope and unity, conviction and common purpose" (BBC, 2010). Already the community sector is concerned about the reconstruction of the welfare state with the release of the white paper 21st Century Welfare by Secretary of State for Work and Pensions, Iain Duncan Smith. Categories of the "deserving" and "undeserving" welfare recipient have transmogrified into a belief that all welfare recipients are bereft. These shifts are a far cry from the aspirations of economist and civil servant William Beveridge who, in 1942, called for a new start to appease the suffering of a war weary population through a new system of social security, which influenced the development of social welfare in Australia. The Beveridge Report, which sold 630,000 copies, called for an attack on the five giant evils: want, disease, ignorance, squalor and idleness (Kynaston, 2007). Although 68 years have passed since Beveridge's clarion call, these evils remain urgent and unresolved. JoSI is commissioned through its facilitation of research and commentary to explore these five giants with a modern and internationalised inflection.

Border control, immigration and religious and cultural diversity have played out globally in exciting and ugly ways. The world watched the rescue of the last of the 33 miners in Chile after 69 days underground and learned of the challenging lives of the Chilean working poor, and dangerous health and safety conditions experienced by miners in the quest to harness wealth-creating resources (Warren, 2010). The Netherlands election of June 10 saw Geert Wilders from the right-wing Freedom Party (PVV) gain 22 seats and hold the balance of power. Wilders was reported as saying:

It is five minutes to midnight, ... I say stop the mass immigration from Muslim countries - not because the people are bad, but because our cultural heritage and society, based on Christian and Judaic values, on humanity, is better than the Islamic... If we don't deal with this and don't stop immigration, because of [misguided] politically correct reasons, then we'll lose Europe (cited in Horovitz, 2010). 
Wilders provoked intense discussion about the complex issues of immigration, integration and the role of religion in public life. In France the proponents of the call to ban the burka or niqab, state their argument is based on the French commitment to equality as a civic value and the appeal to women's rights, and not racism or xenophobia. JoSI provides a forum for these broader and passionate debates about notions of equality and the politics of difference. Moving from the turmoil of the world stage to the site of the journal, in March JoSI issued an invitation for papers. The response has been terrific and we have had to hold a number of papers over to the third issue. The contributors to this issue include practitioners working in nongovernment organisations, independent commentators and researchers from a range of universities based in Australia (ACT, NSW, VIC and QLD), Scotland and Britain. Papers come from the disciplines of youth work, child and family studies, social health, education and social work.

Issue 2 presents rich commentary, argument and research around social inclusion. Theory and praxis are interweaved, pointing to a complexity of conceptual relations, ideas and the on-the-ground realities. The five refereed articles push the boundaries of the meaning of social inclusion.

Julie Allan's piece draws on that rich South American tradition of conscientisation through education. Recalling the Salvadoran underground radio network of the 1970's Radio Venceremos (We Shall Overcome), the Venezuelanfounded El Sistema, literally means "social action for music." Since 1975 it has enabled 250,000 children from poor communities to attend music schools. Sistema Scotland is an example of the international carriage of ideas and movements. Allan's paper captures the spirit of opening up creative and imaginative space for children from a range of backgrounds. The beauty of this piece is that is does not restrict itself to a descriptive commentary of the program but instead engages in a rigorous theoretical analysis of the boundaries of social inclusion and asks tough questions about measuring impacts of social initiatives. Additionally, Allan poses a tension between affirmative directive strategies and more mainstreamed initiatives, especially as these issues relate to the best allocation of resources.

Social inclusion research is challenged to avoid the conflation and simplification of operational concepts affecting our understanding of identity development and social exclusion. A good journal becomes a forum for debating complex ideas in grounded research. Beth $\mathrm{R}$ Crisp draws upon her research into Scottish youth and commentaries from Britain and New York in her paper Belonging, connectedness and social exclusion. Crisp's remarks are pertinent to challenges around community integration, especially for those individuals who may have previously lived in congregative care and are now "integrated" into social housing.

The transformative power of concepts can sometimes be arrested, co-opted and reinterpreted by governments that subsume them into policy and discourse in such a way as to disempower and no longer disrupt (Alcoff \& Gray,1993). Macfarlane takes the reader on a tour of recent pronouncements around social inclusion by the Australian Federal Government. Employing the insights of theorist Foucault, Macfarlane is interested in the "truth effects" of the repetition of discourses of inclusiveness. She does this in a creative way using three vignettes around climate change, (proper) parenting and sport, thereby visiting a familiar theme in this issue around the exclusion/inclusion binary.

Lopez and Lewis bring fresh eyes to the critical issue of service-user engagement in research. With the drive toward emancipatory research and active 
participation of the subjects of research as partners in the research process, 'On the inside' is timely. The article addresses competing relationships between research stakeholders. The authors raise concerns about the psycho-social consequences of "insider research.” Further exploration is required as more people from disadvantaged backgrounds take up educational and research opportunities. The key message is that partnerships change the relations of research production and research outcome.

The proliferation of commentary around the Commonwealth Games held in Delhi, India, brings into stark relief some of the paradoxes around the rhetoric and the reality of social inclusion. The UN's Special Rapporteur, Raquel Rolnik, identified the games as a key factor in decreasing shelters for the 150,000 homeless in Delhi (Bhalla, 2010). The games resulted in emptying the streets of 100,000 itinerant workers and beggars. When memories of past struggles for survival and social inclusion grow dim, history may repeat itself. From 1877-1879 during the short period of the British colonial rule in India, over 11 million people died as a result of famine. These were not accidental deaths but were a consequence of government and community response to misfortune. Viceroy Lytton ordered his people to discourage relief work arguing that "...mere distress is not a sufficient reason for opening a relief work” (cited in Maitra, 2010). Jen Couch's piece on Delhi street children is timely. Our lives, Our say will provoke, as Couch problematises the notion of childhood with all of its western contingencies and tests how such notions travel within a Delhi streetscape in the work of community organisation Butterflies. The article beckons a reappraisal of the conceptual markers of "child labour" and makes linkages with various international norm creating conventions and on-the-ground participatory structures like the Bal Mazdoor Child Workers Union.

Finally, Issue 2 of JoSI contains three commentaries. The first is of the launch speech of the Honourable Michael Kirby, AC CMG, on April 26. In the spirit of this issue Lyn Bender provides some food for thought on the ongoing conflict in the Middle East, and the final piece by Sylvia Anton documents the importance of libraries in the lives of communities.

Dr Fiona Kumari Campbell

School of Human Services and Social Work, Griffith University

On behalf of the Editorial Team

\section{References}

BBC News (2010, May 12). Cameron and Clegg pledge 'united' coalition. Retrieved from http://news.bbc.co.uk/2/hi/8676607.stm

Alcoff, L. \& Gray, L. (1993). Survivor Discourse: Transgression or Recuperation? Signs, Winter, 260 290.

Bhalla, N. (2010, June 15). India shuns poor in Commonwealth Games makeover. AlertNet: Alerting humanitarians to emergencies. Retrieved from http:/www.alertnet. org/ db/an_art/55867/2010/05/15-144521-1.htm

Horovitz, D. (2010, June 9). Wilders hails Israel 'fighting jihad'. The Jerusalem Post. Retrieved from http://www.jpost.com/International/Article.aspx?id=177901

Kynaston, D. (2007). Austerity Britain 1945 - 1950. London: Bloombury.

Warren, M. (2010). Chile miners: From world fame to humble homes, USA Today. Retrieved from http://www.usatoday.com/news/world/2010-10-17-chile-mine-collapse_N.htm?csp=34news

Maitra, R. (2010). Will Singh preside over New Indian Famine? EIR Economics, April 23, pp. 48 - 52. 
